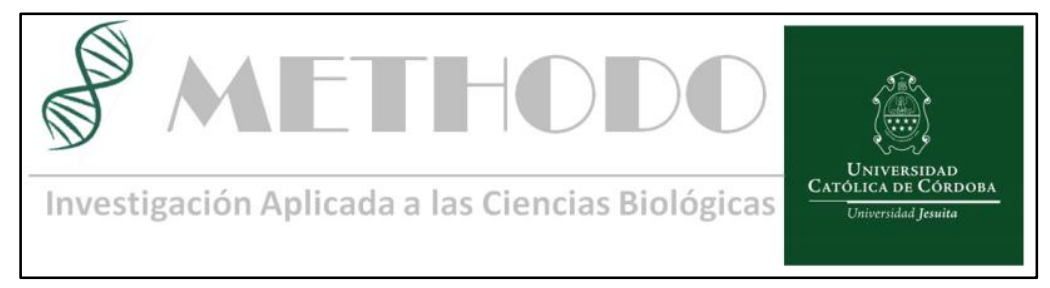

ARTICULO ORIGINAL Methodo 2017;2(1):16-18 DOI: $10.22529 / \mathrm{me} .2017 .2(1) 03$

\title{
Comparación de ortesis para el tratamiento de la artrosis de la base del pulgar*
}

\section{Compare splint for patients with thumb osteoarthritis $(O A)^{*}$}

${ }^{*}$ Resumen deTrabajo Presentado en las XIII Jornadas de Investigación de la Clínica Universitaria Reina Fabiola- Diciembre de 2016

Tuljak $A^{1}$, López Pérez $M^{1}$, Falco $D^{1}$, Bertoli $A^{1}$, Sánchez Freites $\mathrm{G}^{1}$, Blanco F1, Saddi $\mathrm{P}^{1}$.

\section{RESUMEN}

\section{Introducción:}

El tratamiento de la osteoartritis (OA) tiene como primer objetivo reducir el dolor y mejorar la función de la articulación afectada.

La primera indicación para el tratamiento conservador de la rizartrosis es la inmovilización. La intención de inmovilizar es proveer soporte a la articulación carpometacarpiana (CMC) del pulgar mientras se permiten movimientos funcionales de la mano. Hay una variedad de ortesis para el pulgar disponibles, tanto prefabricadas como hechas a medida, y en diferentes tipos de material.

Lamentablemente no hay lineamientos específicos del tipo de ortesis adecuada para la OA de la articulación CMC. EI abordaje del Terapista Ocupacional incluye la consideración de la utilización de ortesis.

Además el Terapista Ocupacional confecciona ortesis termoconformadas hechas a medida.

\section{Objetivo:}

Evaluar la efectividad de las ortesis termoconformadas inmovilizadoras de las articulaciones CMC y Metacarpofalangica (MCF) del pulgar vs. las ortesis termoconformadas inmovilizadoras de la articulación CMC.

\section{Pacientes y método:}

Ensayo clínico no farmacológico de tecnología médica de riesgo no significativo, usando un diseño cruzado de nueve semanas de duración con dos períodos de tratamiento de cuatro semanas cada uno y una semana intermedia de washout (sin ortesis). En el primer período de tratamiento al paciente se le asignó aleatoriamente una ortesis corta o la larga que utilizó durante cuatro semanas y luego de una semana de washout cambió a la otra durante otras cuatro semanas.

El estudio se realizó con pacientes derivados consecutivamente asignados al azar a fin de un tratamiento diferente.

Revista Methodo: Investigación Aplicada a las Ciencias Biológicas. Facultad de Medicina. Universidad Católica de Córdoba. Jacinto Ríos 571 Bo Gral. Paz. X5004FXS. Córdoba. Argentina. Tel.: (54) 351 4517299 / Correo: methodo@ucc.edu.ar / Web: methodo.ucc.edu.ar | ARTICULO ORIGINAL Methodo 2017;2(1):16-18 
Tuljak A, López Pérez M, Falco D, Bertoli A, Sánchez Freites G, Blanco F, Saddi P _ Comparación de ortesis para el tratamiento de la artrosis de la base del pulgar

El dolor se evaluó con la Escala Visual

Analógica (EVA). La capacidad funcional manual se evaluó con la Sub Escala

Funcional del Australian Canadian

Osteoarthritis Hand Index versión

(AUSCAN; Queensland, Australia), validada al español.

\section{Resultados}

Se incluyeron 18 pacientes, 13 (72\%) eran de sexo femenino y tenían una mediana $(p$ 25-75) edad de 59.00 (55.00-66.50) años. En cuanto al estadio radiológico 1 (5.6\%) paciente tenía estadío radiológico Eaton I, 10 (55.6 \%) Eaton II, y 7 (38.9\%) Eaton III. Siete pacientes (38.9\%) comenzaron la intervención con la ortesis corta y 11 $(61.1 \%)$ con la ortesis larga. El dolor disminuyó significativamente en el primer período: al día 0 la mediana de dolor fue 7.5 (5.00-9.00), en comparación con el día 28 donde la mediana fue de 3.00 (2-6.25) $(p=000.1)$. La función mejoró significativamente en el primer período; la mediana de función manual al día 0 fue 0.54 (00.47-00.68), en comparación con el día 28 que fue de 0.76 (0.51-0.86) $(p=0.028)$. No se observaron cambios significativos en dolor y función en el segundo período.

No hubo diferencia en el tipo de ortesis asignada de acuerdo a mano dominante, mano tratada, uso de analgésicos y estadio de Eaton, pero hubo una mayor tendencia de utilizar la ortesis corta en ocupaciones de carga media, de 12.00 pacientes (66\%), $7.00(58,3 \%)$ ortesis cortas, versus 5.00 $(41,7 \%)$ ortesis larga $(p=0.017)$. Para pacientes con ocupaciones de carga liviana de 6.00 pacientes (33,3\%), 6.00 (100\%) tuvieron una tendencia de utilizar ortesis largas $(p=0.017)$.

\section{Conclusiones}

Independiente del modelo de ortesis que se utilice, en este estudio se observó una mejoría clínica de los pacientes tanto en intensidad de dolor como en la función al primer mes de tratamiento. Estos hallazgos indicarían que este tipo de intervención terapéutica es positiva en rizartrosis.

\section{ABSTRAC Introduction:}

The treatment of osteoarthritis (OA) has as its primary objective to reduce pain and improve function of the affected joint.

The first indication for conservative treatment is immobilization. The intention is to provide support to immobilize the carpometacarpal (CMC) of the thumb while functional hand movements are allowed.

There are a variety of thumb splints available, both prefabricated and custommade, and different types of material. Unfortunately there are no specific guidelines on the type of correct splint for OA of the CMC joint. The Occupational Therapist approach includes consideration of the use of orthotics.

Objective: Analyze the effect of two different splints: thermoformed orthotics immobilizing the CMC and metacarpophalangeal (MCP) joints of the thumb vs. the thermoformed orthotics immobilizing the CMC joint, on hand function and pain in individuals with $\mathrm{CMC}$ OA.

\section{Patients and methods:}

Non-pharmacological medical technology clinical trial no significant risk, using a two- 
Tuljak A, López Pérez M, Falco D, Bertoli A, Sánchez Freites G, Blanco F, Saddi P _ Comparación de ortesis para el tratamiento de la artrosis de la base del pulgar

period crossover design, the two four-week treatment periods were separated by oneweek washout period (without splint). A table of random symbols was used to determine treatment order assignments.

Pain was evaluated by the Visual Analogue

Scale (VAS); and hand functional by the

Functional Sub Scale of Canadian

Osteoarthritis Hand Index Australian

version (AUSCAN, Queensland, Australia), validated in Spanish.

\section{Results:}

Eighteen patients were included, 13 (72\%) were female and they were middle-aged ( $p$ 25-75) of 59.00 (55.00-66.50) years. As for the radiological stage 1 (5.6\%) patient had Radiological stage Eaton I, 10 (55.6 \%) Eaton II, y 7 (38.9\%) Eaton III. Seven patients (38.9\%) started the intervention with the short orthosis and 11 (61.1\%) with the long orthosis. The pain decreased significantly in the first period: at day 0 the median pain was 7.5 (5.00-9.00), compared to day 28 where the median was 3.00 (26.25) $(p=000.1)$. The function improved significantly in the first period; the median manual function at day 0 was 0.54 (00.47$00.68)$, compared to day 28 which was 0.76 (0.51-0.86) $(p=0.028)$. There were no significant changes in pain and function in the second period. There was no difference in the type of splint assigned according to dominant hand, hand treated, analgesic use and Eaton stage, but there was a greater tendency to use short orthotics in medium load occupations of 12.00 patients (66\%), $7.00(58.3 \%)$ short orthoses, versus 5.00 (41.7\%) long orthoses ( $p=0.017)$. For patients with light load occupations of 6.00 patients (33.3\%), 6.00 (100\%) had a tendency to use long orthoses ( $p=0.017)$.

\section{Conclusions}

Regardless of the orthotic model used, in this study clinical improvement was observed in both pain intensity and function at the first month of treatment. These findings would indicate that this type of therapeutic intervention is positive in thumb osteoarthritis.

\section{Palabras claves: OSTEOARTRITIS, DOLOR, ORTESIS DEL PULGAR}

\section{Keywords: OSTEOARTRITIS, PAIN, ORTHOSIS OF THE THUMB}

\footnotetext{
${ }^{1}$ Universidad Católica de Córdoba, Argentina. Clínica Universitaria Reina Fabiola, Servicio de Reumatología. Correspondencia: Alejandra Tuljak Servicio de Reumatología- Clínica Universitaria Reina Fabiola. Oncativo 1248 -X5004FHP- Córdoba, Argentina. email: aletuljak@hotmail.com
} 